\section{UMH 1200, a Breeding Line within the Muchamiel Tomato Type Resistant to Three Viruses}

\author{
Santiago García-Martínez, Adrián Grau, Aranzazu Alonso, \\ Fernando Rubio, Manuel Valero, and Juan J. Ruiz ${ }^{1}$ \\ Department of Applied Biology, Universidad Miguel Hernández, Escuela \\ Politécnica Superior de Orihuela, Carretera de Beniel, km. 3.2, 03312, \\ Orihuela, Spain
}

Additional index words. ToMV, TSWV and TYLCV, Tm-2a, Sw-5 and Ty-1
Muchamiel is a tomato landrace that is very popular in southeastern Spain as a result Muchamiel cultivars have a melting texture and mild flavor, are large in size (180 $\mathrm{g}$ to $300 \mathrm{~g}$ ), flattened, and strongly ribbed. However, this landrace is severely endangered and at risk of extinction as a result of its high susceptibility to several viruses such as those caused by the Tomato mosaic virus (ToMV), Tomato spotted wilt virus (TSWV), and Tomato yellow curl virus (TYLCV) (Picó et al., 2002). To introgress genetic resistances to ToMV, TSWV, and TYLCV into the Muchamiel landrace, a breeding program has been carried out over the last 10 years at Miguel Hernández University (Spain). Breeding line UMH 1200 is the first release produced by this breeding program. UMH 1200 has medium-sized fruits (150 to $190 \mathrm{~g}$ ) and organoleptic characteristics similar to those of the original landrace. This homozygous breeding line suffers from a yield penalty compared with the original landrace, which is variable depending on the growing conditions, but its tolerance/resistance to ToMV, TSWV, and TYLCV has been demonstrated in several field and greenhouse trials.

\section{Origin}

Breeding line UMH 1200 was obtained by crossing a Muchamiel line (accession M18, previously selected for high yield and uniformity) with the commercial cultivar Anastasia $\mathrm{F}_{1}$ (Seminis Vegetable Seeds) followed by five generations of backcrossing to the Muchamiel cultivar. Anastasia was used as the donor parent of the $T m-2^{a}, S w-5$, and $T y-1$ genes (Pérez de Castro et al., 2005), conferring resistance to ToMV, TSWV, and TYLCV, respectively. 'Anastasia' is a popular tomato cultivar in Spain with indeterminate and vigorous plant growth as well as good foliage cover. Markerassisted selection was used in each generation

Received for publication 25 Feb. 2011. Accepted for publication 1 June 2011.

This work was partially supported by the Spanish MICINN through projects AGL2002-03329, AGL2005-03946, and AGL2008-03822.

${ }^{1}$ To whom reprint requests should be addressed; e-mail juanj.ruiz@umh.es. of its organoleptic fruit quality. Fruits of the to select the plants that carried the three resistance genes. In addition, a high selection pressure for Muchamiel characteristics was applied during each backcross generation. After five additional generations of selfing and selection, the pure-breeding line, $\mathrm{UMH}$ 1200 , homozygous for the three introgressed virus resistance genes, was selected from a single $\mathrm{BC}_{5} \mathrm{~F}_{5}$ family whose seed was multiplied by self-pollination. UMH 1200 resistances to ToMV and TSWV have been additionally verified by mechanical inoculation assays, and tolerance to TYLCV has been demonstrated in several assays performed in naturally infested fields.

\section{Description}

UMH 1200 is homozygous for the $T m-2^{a}$, $S w-5$, and $T y-1$ genes. As is the case with the cultivar M18, the breeding line has indeterminate growth with intermediate foliage density, ripe fruits do not separate easily from pedicels during harvest, and they sometimes have yellow shoulders. However, the green shoulders of UMH 1200 fruits are frequently less intense than those of the original landrace fruits. In trials carried out in 2010 , no significant differences in yield were found between the breeding line and cultivar M18 in the in the open field crops. Similar results were obtained for the number of fruits per plant and the average fruit weight. These results as well as additional, as-yet unpublished data indicate that the introgression of the resistance genes affects traits of importance for fresh tomatoes. Whether the observed effects are the result of one, two, or three of the introgressed resistance genes, or the result of genes associated through linkage drag, is an important question that we are studying, although the yield problems are mainly as a result of the introgression of the $T y-1$ gene (Rubio et al., 2010). Negative effects associated with the introgression of resistance genes have been reported previously in tomato (Tanksley et al., 1998) as well as in other crops (Brown, 2002; Lewis et al., 2007). However, the comparison of the sensory profiles and volatile composition of the breeding line to the original landrace during cold storage indicated that organoleptic fruit quality had been recovered through the backcrossing program. Moreover, fruits of the breeding line demonstrated better postharvest behavior with higher firmness achieving better scores in odor and aroma at the end of the storage period (Alonso et al., 2010). Because no specific selection for better postharvest behavior was performed during backcrossing, this result could very well be the effect of the introduction of the genetic resistance to the viruses. Data we obtained reinforce the idea that genetic improvement for disease resistance in the Muchamiel landrace can be achieved without reducing the sensory quality and aroma complexity of the fruits (Alonso et al., 2009).

\section{Use}

Breeding line UMH 1200 has genetic tolerance/resistance to the three most important viruses in tomato in southeastern Spain. The incidence of these viruses greatly reduces the profits obtained by farmers and even makes the cultivation of landraces nonviable in many greenhouse (Table 1). However, there was a very important yield decrease in UMH 1200

Table 1. Yield traits, titratable acidity (TA), and soluble solids concentration (SSC) of the breeding line UMH 1200, the Muchamiel landrace (accession M18). and Boludo $F_{1}$, grown in the open field (2009 and 2010) and greenhouse (2010), in the spring-summer crop cycle.

\begin{tabular}{|c|c|c|c|c|c|}
\hline & $\begin{array}{c}\text { Marketable } \\
\text { yield } \\
(\mathrm{kg} / \text { plant })^{\mathrm{z}}\end{array}$ & $\begin{array}{l}\text { Avg fruit } \\
\text { wt }(g)^{z}\end{array}$ & $\begin{array}{c}\text { Fruit } \\
\text { number } \\
\text { per plant }{ }^{\mathrm{z}}\end{array}$ & $\begin{array}{c}\text { TA } \\
(\mathrm{g} / 100 \mathrm{~g})^{\mathrm{y}}\end{array}$ & $\begin{array}{c}\text { SSC } \\
\left({ }^{\circ} \text { Brix }\right)^{y}\end{array}$ \\
\hline \multicolumn{6}{|l|}{ Open field 2009} \\
\hline UMH 1200 & $2.05 \mathrm{a}^{\mathrm{x}}$ & $145 \mathrm{a}$ & $14.7 \mathrm{a}$ & $0.53 \mathrm{a}$ & $4.6 \mathrm{a}$ \\
\hline Accession M18 & $3.14 \mathrm{~b}$ & $220 \mathrm{~b}$ & $14.1 \mathrm{a}$ & $0.54 \mathrm{a}$ & $4.3 \mathrm{a}$ \\
\hline Boludo $\mathrm{F}_{1}$ & $4.25 \mathrm{c}$ & $101 \mathrm{a}$ & $40.0 \mathrm{~b}$ & $0.60 \mathrm{~b}$ & $5.4 \mathrm{~b}$ \\
\hline \multicolumn{6}{|l|}{ Open field 2010} \\
\hline UMH 1200 & $2.15 \mathrm{a}$ & $190 \mathrm{a}$ & $10.7 \mathrm{a}$ & $0.37 \mathrm{a}$ & $4.9 \mathrm{~b}$ \\
\hline Accession M18 & $4.75 \mathrm{~b}$ & $227 \mathrm{~b}$ & $20.7 \mathrm{~b}$ & $0.33 \mathrm{a}$ & $4.2 \mathrm{a}$ \\
\hline Boludo $F_{1}$ & $4.82 \mathrm{~b}$ & $169 \mathrm{a}$ & $24.3 \mathrm{~b}$ & $0.71 \mathrm{~b}$ & $7.4 \mathrm{c}$ \\
\hline \multicolumn{6}{|l|}{ Greenhouse 2010} \\
\hline UMH 1200 & 3.83 & $141 \mathrm{~b}$ & $27.3 \mathrm{a}$ & $0.30 \mathrm{a}$ & $3.9 \mathrm{a}$ \\
\hline Accession M18 & 4.40 & $182 \mathrm{c}$ & $24.5 \mathrm{a}$ & $0.34 \mathrm{~b}$ & $3.8 \mathrm{a}$ \\
\hline Boludo $\mathrm{F}_{1}$ & 4.84 & $102 \mathrm{a}$ & $50.2 \mathrm{~b}$ & $0.48 \mathrm{c}$ & $4.6 \mathrm{~b}$ \\
\hline
\end{tabular}

${ }^{\mathrm{z}}$ Mean of six plants per plot for two replicates.

${ }^{y}$ Mean of six fruits per plot for two replicates.

${ }^{x}$ Mean values in a column followed by a different letter are significantly different according to Duncan's multiple range test $(P<0.05)$. 
areas, especially in the open field. Despite the yield decrease associated with the introgressed resistances, the breeding line is available for cropping in open fields, where the viruses' incidence is especially intense, allowing farmers to obtain an acceptable harvest. This breeding line may also be used in breeding programs to facilitate the introgression of the resistance genes into other landraces. We are also developing $\mathrm{F}_{1}$ hybrids by crossing UMH 1200 with other selected Muchamiel lines to increase yield by using the genetic resistance in a heterozygous state.

\section{Availability}

Small trial seed samples of the UMH 1200 breeding line are available for research purposes (contact the authors).

\section{Literature Cited}

Alonso, A., S. García-Martínez, L. Vázquez-Araujo, J.J. Ruiz, and A.A. Carbonell-Barrachina. 2010. Comparative post-harvest behaviour of traditional and virus-resistant Muchamiel tomatoes. J. Sci. Food Agr. 90:1056-1062.

Alonso, A., L. Vázquez-Araújo, S. García-Martínez, J.J. Ruiz, and A.A. Carbonell-Barrachina. 2009. Volatile compounds of traditional and virus-resistant breeding lines of Muchamiel tomatoes. Eur. Food Res. Technol. 230:315323.

Brown, J.K.M. 2002. Yield penalties of disease resistance in crops. Curr. Opin. Plant Biol. 5: 339-344.

Lewis, R.S., L.R. Linger, M.F. Wolff, and E.A. Wernsman. 2007. The negative infuence of $\mathrm{N}$-mediated TMV resistance on yield in tobacco: Linkage drag versus pleiotropy. Theor. Appl. Genet. 115:169-178.
Pérez de Castro, A., M.J. Díez, and F. Nuez. 2005. Evaluation of breeding tomato lines partially resistant to Tomato yellow leaf curl Sardinia virus and Tomato yellow leaf curl virus derived from Lycopersicon chilense. Can. J. Plant Pathol. 27:268-275.

Picó, B., J. Herraiz, J.J. Ruiz, and F. Nuez. 2002. Widening the genetic basis of virus resistance in tomato. Sci. Hort. 94:73-89.

Rubio, F., S. García-Martínez, A. Alonso, A. Grau, M. Valero, and J.J. Ruiz. 2010. Introgressing resistance genes into traditional tomato varieties: Effects on yield and quality. 28th International Horticultural Congress, Lisboa, Portugal.

Tanksley, S.D., D. Bernachi, T. BeckBunn, D. Emmatty, Y. Eshed, S. Inai, J. Lopez, V. Petiard, H. Sayama, J. Uhlig, and D. Zamir. 1998. Yield and quality evaluations on a pair of processing tomato lines nearly isogenic for the $\mathrm{Tm} 2^{\mathrm{a}}$ gene for resistance to the Tobacco mosaic virus. Euphytica 99:77-83. 